\title{
Designing of Alternative Polymeric Nano-Chelator for Treatment in Acute Iron Poisoning by Molecular Imprinting Approach
}

\section{Akut Demir Zehirlenme Tedavileri için Moleküler Baskılama Yaklaşımı ile Alternatif Polimerik Nano Şelatörlerin Tasarlanması}

\section{Veyis Karakoç ${ }^{\circ}$}

Eldivan Vocational School of Health Services, Çankırı Karatekin University, Çankırı, Turkey.

\section{ABSTRACT}

\begin{abstract}
The aim of this study is to develop an alternative polymeric chelating agent for rapid and selectively removal with high capacity of iron $\left(\mathrm{Fe}^{3}\right)^{+}$ions from the gastrointestinal (GI) tract for the oral treatment of acute iron poisoning. For this purpose, $\mathrm{Fe}^{3+}$ imprinted poly(hydroxyethyl methacrylate- $\mathrm{N}$-methacryloyl-(I)- glutamic acid) (HEMA-MAGA) nanoparticles were synthesized by surfactant free emülsiyon polymerization. Molecular imprinting (MIP) technique was used to enhance the selectivity of nanoparticles. Due to being carboxyl and amide groups on the MAGA monomer, it was chosen as a chelating agent for $\mathrm{Fe}^{3+}$ ions. Before the synthesizing of $\mathrm{Fe}^{3+}$ imprinted polymer, $\mathrm{Fe}^{3+}$ ions were complexed with ( $\mathrm{N}$-methacryloyl-(I)glutamic acid) MAGA and then $\mathrm{Fe}^{3+}$ imprinted nanoparticles were synthesized in the presence of this $\mathrm{Fe}^{3+}$-MAGA complexes. Poly(HEMA-MAGA) nanoparticles were characterized by infrared spectroscopy (FTIR), atomic force microscopy (AFM) Average particle size and size distribution also determined by zeta sizer. The specific surface area and mead diameter of the $\mathrm{Fe}^{3+}$ imprinted poly(HEMA-MAGA) nanoparticles was $895 \mathrm{~m}^{2} \cdot \mathrm{g}^{-1}$ and $95.3 \mathrm{~nm}$, respectively. The maximum $\mathrm{Fe}^{3+}$ ions binding capacity of the poly(HEMA-MAGA) nanoparticles at $\mathrm{pH}: 4.0$ were $206.4 \mathrm{mg} . \mathrm{g}^{-1}$ nanoparticles in intestinal mimicking solution(IMS). $\mathrm{Fe}^{3+}$ removal performance of the $\mathrm{Fe}^{3+}$ imprinted poly(HEMA-MAGA) nanoparticles with presence of other ions, optimum medium $\mathrm{pH}$, temperature and equilibrium binding time were also investigated. $\mathrm{Fe}^{3+}$ removal studies were performed in both aqueous solution and intestinal mimicking solution. The results indicate that $\mathrm{Fe}^{3+}$ imprinted poly(HEMAMAGA) nanoparticles is an alternative chelating agent for the selective $\mathrm{Fe}^{3+}$ ions removal in a short time and with very high capacity.
\end{abstract}

\section{Key Words}

Acute iron poisoning, iron removal, molecularly imprinted polymers (MIP), iron imprinting, glutamic acid.

\section{öz}

u çalışmanın amacı akut demir zehirlenmelerinin tedavisi için, sindirim sisteminden demir iyonlarının yüksek kapasitede ve hızı bir şekilde uzaklaştırılmasına yönelik alternatif polimerik şelatlayıcı geliştirilmesidir. Bu amaçla surfaktansız emülsiyon polimerizasyon yöntemi ile $\mathrm{Fe}^{3+}$ iyonları baskılanmış poli(hydroxyethyl methacrylate- $\mathrm{N}$-methacryloyl-(I)- glutamic acid) (HEMA-MAGA) nanopartikülleri sentezlendi. Moleküler baskılama yöntemi nanopartiküllerin seçiciliğini artırmak için kullanıldı. Karboksil ve amid grupları olması nedeniyle MAGA monomeri Fe ${ }^{3+}$ iyonlarını şelatlayıcı ajan olarak seçildi. $\mathrm{Fe}^{3+}$ iyonları baskılanmış polimer sentezlenmeden önce $\mathrm{Fe}^{3+}$ iyonları MAGA monomeri ile kompleksleştirildi ve sonra $\mathrm{Fe}^{3+}$ MAGA kompleksinin varlığında Fe ${ }^{3+}$ baskılanmış nanopartiküller sentezlendi. Poli(HEMA-MAGA) nanopartiküller infrared spektroskoisi (FTIR), atomik kuvvet mikroskopisi (AFM) ve partikül boyut ve boyut dağılımıda zeta sizerla karakterize edildi. $\mathrm{Fe}^{3+}$ baskılanmış poli(HEMA-MAGA) nanopartiküllerin yüzey alanı ve ortalama çapı sırasıyla $895 \mathrm{~m}^{2} \cdot \mathrm{g}^{-1}$ ve $95.3 \mathrm{~nm}$ dir. Poli(HEMA-MAGA) nanopartiküllerin maksimum $\mathrm{Fe}^{3+}$ iyonları bağlama kapasiteleri yapay mide suyunda pH: 4.0 te 206.4 mg. $\mathrm{g}^{-1}$ nanopartiküldür. $\mathrm{Fe}^{3+}$ baskılanmış poli(HEMA-MAGA) nanopartiküllerin $\mathrm{Fe}^{3+}$ iyonları uzaklaştırma performansları başka iyonlar varlığında, optimum ortam $\mathrm{pH}^{\prime} ı$, sıcaklık ve denge bağlanma zamanı incelendi. Fe ${ }^{3+}$ iyonları uzaklaştırma çalışmaları hem sulu çözeltide hemde yapay mide suyu çözeltisinde yapıldı. Yapılan tüm bu deneysel çalışmaların sonuçları $\mathrm{Fe}^{3+}$ baskılanmış poli(HEMA-MAGA) nanopartiküllerin $\mathrm{Fe}^{3+}$ iyonlarının çok kısa zaman içerisinde ve çok yüksek kapasitede uzaklaştırmada alternatif şelatlayıcı ajan olabileceğini göstermektedir.

\section{Anahtar Kelimeler}

Akut demir zehirlenmesi, demir uzaklaştırılması, moleküler baskılanmış polimerler, demir baskılama, glutamik asit. 


\section{INTRODUCTION}

ron is a trace element, and plays several important roles in human body. Iron is the component of metaloprotein and cofactor of some enzymes as well as it participates essential biochemical activities such as oxygen transport, electron transfer, catalysis and energy metabolism. Iron also participates in many biochemical, metabolic and biological process. Human body contains $5 \mathrm{gr}$ iron and 10 $\mathrm{mg}$ iron is absorbed in duodenum and upper jejunum by diets, daily $[1,2]$.

Although iron has very important function in body, all over the world many people suffer from iron deficiency, especially women lost iron during menstrual cycles. Consumption of inadequte iron containing diet cause to iron deficiency or anemia. In order to prevent or treatment of iron deficiency or anemia, iron containing supplements are used. Generally many supplements are taken orally as a tablets, which are mostly contain iron (II) sulfate. Due to the common usefulnes, this iron tablets are available without prescription and kept at many home. Produced iron supplement for compensation of iron deficiency can looks like candy because they brightly colored and sugar coated. So they are attract children attention. Many children reach easly this supplement or iron containing vitamin and syrup. Mostly, a vitamin or mineral suplement tablet contains 60 mg of elemental iron [3].

Like inadequate uptake, excess intake of iron is also problem for human. Because there is no regulation mechanism for excess iron excretion from the body. Ingestion of 60 mg. $\mathrm{kg}^{-1}$ body weight of iron or serum iron levels more than $500 \mu \mathrm{g} \cdot \mathrm{dL}^{-1}$ can cause toxicity, and may be lethal for children. It can cause serious risk of acute liver failure and eventually death. Iron is corrosive to the gastrointestinal mucosa and high blood level of free iron ions can react with peroxides to produce free radicals, which are highly reactive and can damage to DNA, proteins, lipids other cellular components and than promote cell death and tissue injury, finally organ failure especially liver. Non bounded iron ions on the transferin accumulate primarily in the liver, spleen, heart, kidneys and lungs [4].

Iron poisoning can be acute or chronic. Chronic iron poisoning is caused by result of accumulation of iron in body because of frequently blood transfusions of in $B$ thalassemia, hereditary hemochromatosis and sickle cell anemia patients [5].
Since humans do not have an iron excretion pathway, excess iron is eliminated from the body with chelating agents. For the chronic iron poisoning treatment, desferrioxamine (DFO), deferiprone (L1) and desferasirox (ICL-670), which are clinically approved iron chelators, are used [6].

A desferrioxamine as the most common drug, is an iron chelating agent, and used since 1960. However, DFO with the longest clinical experience in treating iron poisoning, has some drawback such as its high cost, lack of oral efficiency and major side-effects in the long term neurotoxicity, hypotension, short plasma half life and must be administered by long and frequent subcutaneous infusions (12-24 h/5-6 days/week). There is no orally effective alternative to deferoxamine in the treatment of iron poisoning $[7,8]$.

Acute iron poisoning may be caused by suicidal or accidental ingestion of large amount of iron, either as tablets of iron salts or as constituents of vitamin and mineral supplements or syrups.

In recent years, iron poisoning increased because of wide spread use of iron containing supplements. According to the 2015 Annual Report of the American Association of Poison Control Centers' (AAPCC) National Poison Data System; 4072 single exposures to iron or iron salts, with one major outcome and one death. And, the reports show 2036 case occured in children younger than 5 years, and 3211 were unintentional ingestion [9]. Acute iron poisoning may be cause hemorrhagic nausea vomiting, diarrhea, abdominal pain, hypovolemia or shock acidosis, failure of organs such as liver, heart and kidneys, coma, cardiovascular collapse, and eventually death [10].

The treatment of acute iron poisoning is initiated with gastric lavage and whole bowel irrigation than chelation therapy. Gastric lavage and bowel irrigation should be used as soon as possible to reduce of intestinal absorption of toxic iron ions in 0-6 hours $[11,12]$.

In treatment of acute iron poisoning, early recognition is very important to reduce the effects of poisoning and to prevent morbidity and mortality. Therefore, designing an orally active chelating agent for preparing of lavage solutions are gaining importance. Because the intestinal absorbtion of swallowed iron can be blocked with using oral active chelating agent than remove ex- 
cess iron ions through the faecal excretion routes. Altough activated carbon is also commonly used as the adsorbent in poisoning treatment, but it does not adsorb iron ions $[13,14]$.

Many researcher have been studied to develop alternative chelators such as covalently attached DFO to dextran and hydroxyethyl starch (HES), degradable PEG based copolymers, hydroxamic acid group containing hydrogels, dendrimeric iron chelators and polymer based chelators for treatment acute iron poisoning. Therefore, several techniques and chelation therapies have been investigated [15-20]. Among them, polymeric chelating agents with their superior feature because of non-toxicity, high affinity and specifty to iron ions, biocompatibility, forming fast and insoluble complex, preventing the absorption of $\mathrm{Fe}^{3+}$ ion in $\mathrm{Gl}$ tract, promoting the removal of iron and orally active is the most promising adsorbent [21-29].

Molecular imprinting is a method that used in the synthesis of polymeric structures with the high selectivity and specifity towards the target molecules or ions [30]. Polymerization is performed in the presence of the target and functional monomer. After removal of the target molecule from the polymeric matrix, three dimensional (3D) chemically selective binding sites also stated synthetic receptors are obtained. In molecular imprinting method, secondary interactions such as hydrogen bonding, electrostatic or hydrophobic interactions play an important role [30]. Molecular imprinted polymers because of their unique feutures like being easy to prepare, stable, cost effectiveness and capable of molecular recognition have recieved much attention in various field such as biotechnology, environmental, sensors, medicine, etc. [31-35]. Synthetic receptors obtained via MIP technology are not affected by harsh condition such as high temperature, $\mathrm{pH}$ and organic solvent when comparating biological receptors. Nanoparticle has been receiving attention as an adsorbent due to its large surface-to-volume ratios and unique chemical and physical properties [36]. The large surface area of the nanoparticles can increase their adsorption capacities and reduce adsorption time, which are very important advantages because of reaching to high adsorption capacity in a short time. Therefore, it is useful for the removal of metal ions from varios medium in comparation with conventional adsorbents. Polymeric nanoparticles is the most promising alternative of the conventional materials, which are used in sepa- ration and purification technology as well as medical imaging, drug delivery, etc. $[37,38]$.

In this study, HEMA based polymeric nanoparticles were synthesized for the treatment of acute iron poisoning. Backbone of poly(HEMA-MAGA) nanoparticles carring glutamic acid increase biocompatiblity of polymer. MAGA was selected as $\mathrm{Fe}^{3+}$ complexing monomer. Because primary amine groups and pendant carboxy groups of MAGA form complexes with $\mathrm{Fe}^{3+}$ ions. Strong complex formation occurs between carboxylic groups and iron ions. By using mip technique, selectivity of polymeric chelating agent to $\mathrm{Fe}^{3+}$ ions was enhanced. Due to the their nano size, prepared nanoparticles have high adsorption capacity and reaches maximum adsorption capacity in a very short time. Our strategy is to remove $\mathrm{Fe}^{3+}$ ions before absorption of intestinal system with using chelating agent via orally treatment. After adsorption of the $\mathrm{Fe}^{3+}$ ions onto the nanoparticles from the gastrointestinal tract system, removal of excess iron will come true through the faecal excretion routes.

\section{EXPERIMENTAL}

\section{Chemicals}

L-Glutamic acid hydrochloride and methacryloyl chloride, potassium persulfate (St Louis, USA) were purchased from Sigma (St. Louis, MO USA). Hydroxyethyl methacrylate (HEMA) and ethylene glycol dimethacrylate (EGDMA) were obtained from Fluka A.G. (Buchs, Switzerland). Poly(vinyl alcohol) (PVAL; MW, 100,000; 98\% hydrolyzed) was supplied from Aldrich Chem (USA). All other chemicals were of reagent grade and were purchased from Merck AG (Darmstadt, Germany). Stock solution of $1000 \mathrm{mg} \cdot \mathrm{L}^{-1} \mathrm{Fe}^{3+}$ was prepared by dissolving iron nitrate $\left(\mathrm{Fe}\left(\mathrm{NO}_{3}\right)_{3} \cdot 9 \mathrm{H}_{2} \mathrm{O}\right)$ (Merck, Darmstadt, Germany). Standard iron solutions were prepared daily by dilution of the stock solutions. Barnstead (Dubuque, IA, USA) ROpure LP reverse osmosis unit of deionized water was used in the all experiments.

\section{Preparation of $\mathrm{Fe}^{3+}$-MAGA complex and $\mathrm{Fe}^{3+}$ imprinted nanoparticles}

Firstly, MAGA monomer was synthesized, then MAGA$\mathrm{Fe}^{3+}$ complexes was formed, and finally $\mathrm{Fe}^{3+}$ imprinted poly(HEMA-MAGA) nanoparticles were prepared. The surfactant free emulsion polymerization method was used for the preparation of $\mathrm{Fe}^{3+}$ imprinted poly(HEMAMAGA) nanoparticles. A preparation procedure is described below. The synthesis of MAGA monomer was 


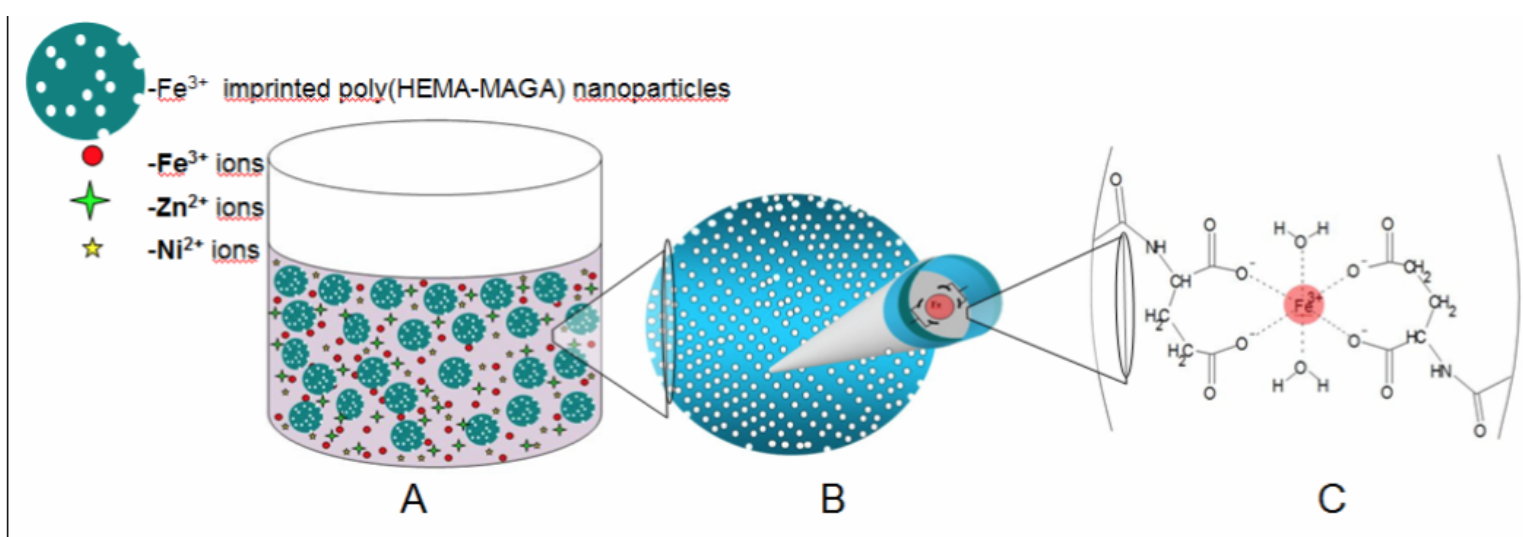

Figure 1. Schematic presentation of experiments. A) $\mathrm{Fe}^{3+}$ binding medium of nanoparticles, which contain competitive ions $\mathrm{Zn}^{2+}$ and $\mathrm{Ni}^{2+}$ B) A single $\mathrm{Fe}^{3+}$ imprinted nanoparticles with tailored cavities for $\mathrm{Fe}^{3+}$ ions C) Complex formation of carboxylic groups and $\mathrm{Fe}^{3+}$ ion.

described as the procedure reported by elsewhere [39].The MAGA-Fe ${ }^{3+}$ complex monomer, was prepared by addition of solid $\mathrm{N}$-methacryloyl-L glutamic acid (MAGA) $(0.430 \mathrm{~g}, 2.0 \mathrm{mmol})$ into $15 \mathrm{~mL}$ solution of ethanol- water mixture $(50 / 50, v / v)$ in a vessel, followed by dissolution of iron nitrate $\left(\mathrm{Fe}\left(\mathrm{NO}_{3}\right)_{3} \cdot 9 \mathrm{H}_{2} \mathrm{O}\right)(0.404$ $\mathrm{g}, 1.0 \mathrm{mmol}$ ) at room temperature by constant stirring (250 rpm) for $3 \mathrm{~h}$. Then, the formed monomer-metal complex (MAGA $-\mathrm{Fe}^{3+}$ ) was filtered, washed with $96 \%$ ethanol, and dried in a vacum oven at $40^{\circ} \mathrm{C}$ for $24 \mathrm{~h}$. After formation of MAGA- $\mathrm{Fe}^{3+}$ complexes, $\mathrm{Fe}^{3+}$ imprinted poly(HEMA-MAGA) nanoparticles were synthesized.

Preparation procedure for polymeric $\mathrm{Fe}^{3+}$ imprinted poly(HEMA-MAGA) nanoparticles is given below. Briefly, the stabilizer, poly(vinyl alcohol) (PVAL, $0.5 \mathrm{~g}$ ), was dissolved in $50 \mathrm{ml}$ deionized water for the preparation of the dispersion phase. Organic phase including HEMA/ EGDMA/Fe-MAGA complex mixture $0.6 \mathrm{ml} / 0.2 \mathrm{ml} / 300$ mg respectively stirred about $30 \mathrm{~min}$ at room temperature then, transferred into the dispersion medium, which was placed in a sealed pyrex polymerization reactor (volume: $250 \mathrm{~mL}$ ), in a thermostatic water bath. KPS $\left(0.5 \mathrm{mg} \mathrm{ml}^{-1}\right)$ used as an initiator, was added polymerization solution and mixed in an ultrasonic bath for $30 \mathrm{~min}$. Polymerization was carried out in a shaking bath with constant temperature at $70^{\circ} \mathrm{C}$, for $6 \mathrm{~h}$. Non-imprinted poly(HEMA-MAGA) nanoparticles were prepared in the same way, without addition of MAGA- $\mathrm{Fe}^{3+}$ complexes. After polymerization, $\mathrm{Fe}^{3+}$ imprinted poly(HEMA-MAGA) nanoparticles were separated from the polymerization medium by the precipating with the a centrifuge (Zentrifugen, Universal $32 \mathrm{R}$, Germany) of $25000 \mathrm{~g}$ for $30 \mathrm{~min}$. Then, it was resuspended in ethanol and water solutions, and washed with ethanol and water several times.
After cleaning procedure, the template $\mathrm{Fe}^{3+}$ ions were removed from the polymeric nanoparticles by using 0.1 $M$ EDTA solution. The MIP nanoparticles were added into $0.1 \mathrm{M}$ EDTA solution for $24 \mathrm{~h}$ at room temperature and with $200 \mathrm{rpm}$ apparatus. This procedure was repeated several times until the template molecule (i.e. $\mathrm{Fe}^{3+}$ ions) could not be detected in the cleaning solutions with inductively coupled plasma-optical emission spectrometer (ICP-OES). Finally, the template free nanoparticles were suspended in deionized water. By using Freeze dryer (lyophilizator), and $\mathrm{Fe}^{3+}$ imprinted nanoparticles get obtained as dry powders, and kept in refrigerator.

\section{Characterization of nanoparticles}

The average size and size distribution of the $\mathrm{Fe}^{3+} \mathrm{imp}-$ rinted poly(HEMA-MAGA) nanoparticles were determined by Nano Zetasizer Nano ZS (NanoS, Malvern Inst. London, UK). Poly(HEMA-MAGA) nanoparticles were dispersed in $3 \mathrm{ml}$ deionized water and placed onto the sample holder. The light scattering was performed at an incidence angle of $90^{\circ}$ and $25^{\circ}$.

The shape and size of the $\mathrm{Fe}^{3+}$ imprinted poly(HEMAMAGA) nanoparticles were analyzed by atomic force microscopy (AFM) (Nanomagnetics Instruments, Oxford, UK) in tapping mode. Samples were scanned with $2 \mu \mathrm{m} . \mathrm{s}^{-1}$ scanning rate at $256 \times 256$ pixels resolution. Scanning was performed at a scan rate of $1.001 \mathrm{~Hz}$ and scan size of $5000 \mu \mathrm{m}$. The tip loading force was minimized to avoid structural changes of the sample

FTIR spectra of the samples were obtained using a FTIR spectrophotometer (Thermo Fisher Scientific, Nicolet iS10, Waltham, MA, USA). The dry nanoparticles (about 
$5 \mathrm{mg}$ ) were mixed with $\mathrm{KBr}(0.1 \mathrm{~g}$, IR Grade, Merck, Germany), and pressed into a tablet form, and the spectrum was recorded with the relevant wave number interval of $4600-400 \mathrm{~cm}^{-1}$.

The surface area of the poly(HEMA-MAGA) nanoparticles was calculated using the following Equation 1:

$N=6 \times 10^{10} \times S / \pi \times \rho_{s} \times d^{3}$

where, $\mathrm{N}$ is the number of nanoparticles per milliliter; $\mathrm{S}$ is the $\%$ of solids; $\rho_{\mathrm{s}}$ is the density of bulk polymer (g. $\mathrm{mL}$ $\left.{ }^{1}\right)$; $d$ is the nanoparticle diameter $(n m)$. The number of nanoparticles in $\mathrm{mL}$ suspension was determined by utilizing from mass-volume graph of nanoparticles. From all these data, specific surface area of the nanoparticles was calculated by multiplying $\mathrm{N}$ and surface area of $1 \mathrm{~g}$ nanoparticle.

\section{$\mathrm{Fe}^{3+}$ removal studies from aqueous solutions}

$\mathrm{Fe}^{3+}$ removal experiments were carried out batchwise in the media at different $\mathrm{pH}$ values. The poly(HEMAMAGA) nanoparticles (10 mg) were added to adsorption medium $(10 \mathrm{~mL})$ in suspended form, and the adsorption was performed in the flasks by stirring magnetically at $200 \mathrm{rpm}$ for $2 \mathrm{~h}$. $\mathrm{Fe}^{3+}$ solutions was prepared from its nitrate salt, $\left(\mathrm{Fe}\left(\mathrm{NO}_{3}\right)_{3} \cdot 9 \mathrm{H}_{2} \mathrm{O}\right)$ by dissolving in deionized water with a conductivity value of $18.2 \mathrm{M} \Omega$ (supplied from Barnstead Nano pure Diamond). Effects of $\mathrm{pH}$ (i.e., 2-7 adjusted with $\mathrm{HCl}-\mathrm{NaOH}$ ) and initial concentration of $\mathrm{Fe}^{3+}$ (i.e., 0-100 mg. $\mathrm{L}^{-1}$ ) on the adsorption rate and capacity were investigated. Due to the importance of fast removal of $\mathrm{Fe}^{3+}$ ions from $\mathrm{Gl}$ tract in acute iron poisoning, adsorption time (15, 30, 45, 60, 90 and $120 \mathrm{~min})$ was also studied. Removal efficiency was determined from the difference between initial and final $\mathrm{Fe}^{3+}$ concentraion in medium by using ICP-OES.

The amount of removed $\mathrm{Fe}^{3+}$ ions per unit mass of the nanoparticles was evaluated by using the mass balance. The removal capacity of the poly(HEMA-MAGA) nanoparticles for $\mathrm{Fe}^{3+}$ was calculated according to the following equation (Equation 2):

$$
\mathrm{Q}=\left[\left(\mathrm{C}_{\mathrm{i}}-\mathrm{C}_{\mathrm{f}}\right) \mathrm{V}\right] / \mathrm{m}
$$

where, $\mathrm{Q}$ is the amount of $\mathrm{Fe}^{3+}$ ions adsorbed onto unit mass of the nanoparticle ( $\left.\mathrm{mg} \cdot \mathrm{g}^{-1}\right) ; \mathrm{C}_{i}$ and $\mathrm{C}_{f}$ are concentration of $\mathrm{Fe}^{3+}$ ions in the initial and in the final solution after treatment, respectively $\left(\mathrm{mg} \cdot \mathrm{mL}^{-1}\right) ; \mathrm{V}$ is the total volume of the solution (L), and $m$ is the mass of the nanoparticles (g).

\section{$\mathrm{Fe}^{3+}$ removal studies from intestinal mimicking solutions}

Preparation of $\mathrm{Fe}^{3+}$ ions contain intestinal mimicking medium (A): For the batchwise adsorption tests, intestinal mimiking solution was prepared [40]. A total of $200 \mathrm{~mL}$ water was added to $125 \mathrm{~mL}$ of a $0.2 \mathrm{M}$ potassium dihydrogen phosphate solution and $95 \mathrm{~mL}$ of 0.2 $M$ sodium hydroxide solution. Then, $24.5 \mathrm{~g}$ of sodium deoxycholate ( $\mathrm{NaDC}$ ) and $16.5 \mathrm{~g}$ sodium cholate $(\mathrm{NaC})$ were added. The $\mathrm{pH}$ was adjusted to $4.0 \pm 0.1$ with $0.2 \mathrm{M}$ sodium hydroxide solution and final volume was made up to $500 \mathrm{~mL}$ using water. After sparging with nitrogen for $30 \mathrm{~min}$, the solution was stored in dark at room temperature.

Preparation of iron standard solution (B): To $500 \mathrm{~mL}$ of (A) solution above, $900 \mathrm{mg}$ of iron sulfate $\left(\mathrm{FeSO}_{4} \cdot 7 \mathrm{H}_{2} \mathrm{O}\right)$ ( $2.7801 \mathrm{~g}, 0.10 \mathrm{~mol}$ ) was added, and the solution was stirred for $2 \mathrm{~h}$ at $50^{\circ} \mathrm{C}$. The solution was then sparged with nitrogen for $30 \mathrm{~min}$ and stored in dark at room temperature.

Binding Experiments: A total of $10 \mathrm{mg}$ of dry nanoparticles was suspended into $20 \mathrm{~mL}$ of intestinal mimicking solution (IMS). The samples were then magnetically stirred for $1 \mathrm{~h}$, at a stirring rate of $100 \mathrm{rpm}$. The solution was centrifuged to separate the nanoparticles, and the supernatant solution was estimated for iron. The amount of removed $\mathrm{Fe}^{3+}$ was calculated by using a calibration curve obtained from the same experiments.

\section{Selectivity studies}

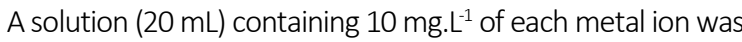
treated with the $\mathrm{Fe}^{3+}$ imprinted nanoparticles at a $\mathrm{pH} 4.0$ in the flasks stirred magnetically at $200 \mathrm{rpm}$. The selectivity of MIP particles for $\mathrm{Fe}^{3+}$ was investigated by using $\mathrm{Cd}^{2+}, \mathrm{Co}^{2+}, \mathrm{Cr}^{3+}$, $\mathrm{Ni}^{2+}, \mathrm{Pb}^{2+}, \mathrm{Zn}^{2+}, \mathrm{Mn}^{2+}$ and $\mathrm{Ni}^{2+}$ as interfering ions since their molecular radius are quite similar with iron. The selectivity studies were performed in intestinal mimicking solution including $10 \mathrm{mg}$ of nanoparticles was weighed and added $20 \mathrm{~mL}$ of above solution containing competitive metal ions in a flask. Flask was magnetically stirred in for $2 \mathrm{~h}$ at a stirring rate $200 \mathrm{rpm}$. The polymer suspension was centrifuged (20.000 rpm for 30 $\mathrm{min}$ ) and concentration of metal ions in the supernatant was determined by ICP-OES. The amount of metal ions bound to the polymer was calculated by difference. 


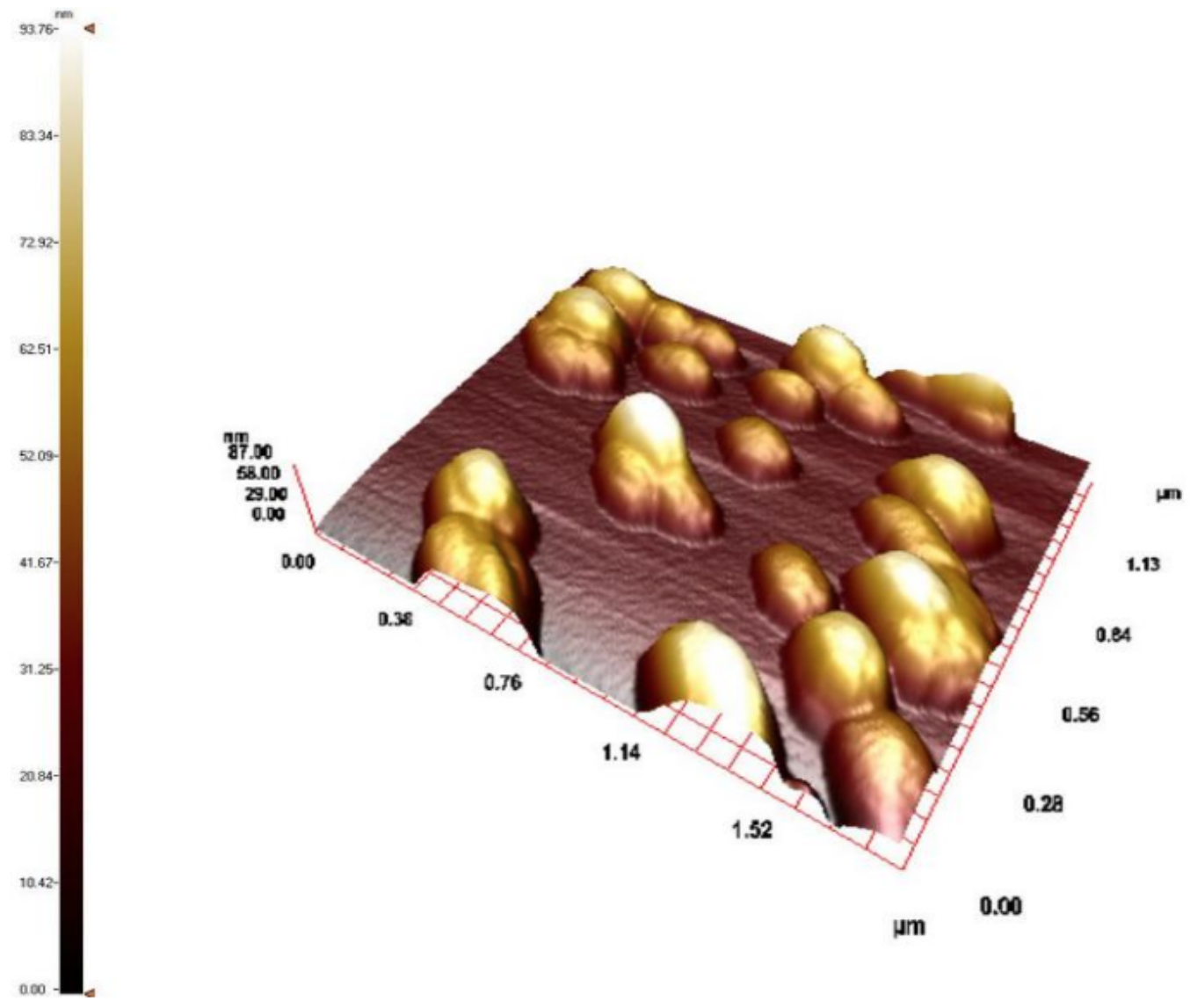

Figure 2. AFM photograph of the poly(HEMA-MAGA) nanoparticles.

Distribution and selectivity coefficients $\left(K_{d}\right)$ of competitive ions with respect to $\mathrm{Fe}^{3+}$ ions were calculated by the following Equation. (3)

$K_{d}=\left[\left(C-C_{f}\right) / C_{f}\right] \times V / m$

Here, $\mathrm{K}_{\mathrm{d}}$ represents the distribution coefficient; $\mathrm{C}_{i}$ and $\mathrm{C}_{\mathrm{f}}$ are the initial and final concentrations of metal ions, respectively. $V$ is the volume of the solution $(\mathrm{mL})$, and $m$ is the mass of particles used (g).

The selectivity coefficient ( $\mathrm{k}$ ) for the binding of $\mathrm{Fe}^{3+}$ in the presence of other competitive metal ions (Equation. 4) can be obtained from equilibrium binding data according to (Equation. 4).

$k=K_{d}$ (iron) $/ K_{d}$ (comp.)

Where, $k$ is the selectivity coefficient, and $k$ represents competitive metal ions.
A comparison of the $k$ values of the MIP nanoparticles allows an estimation of the effect of imprinting on selectivity. The relative selectivity coefficient $\left(k^{\prime}\right)$ is an indicator for competitive binding efficiency of imprinted nanoparticles recognition sites in terms of non imprinted nanoparticles.

A relative selectivity coefficient $k^{\prime}$ (Equation. 5) can be defined as

$k^{\prime}=k_{\text {MINps }} / k_{\text {NINps }}$

\section{RESULTS and DISCUSSION}

\section{Characterization of Nanoparticles}

Size and spherical shape of the nanoparticles provide them high surface area due to this unique feature of nanoparticles used as suitable adsorbent for the adsorption process. The specific surface area of poly(HEMAMAGA) nanoparticles was calculated as $895 \mathrm{~m}^{2} \cdot \mathrm{g}^{-1}$ by using Equation 1. Figure 3 . shows the average size and size dist- 


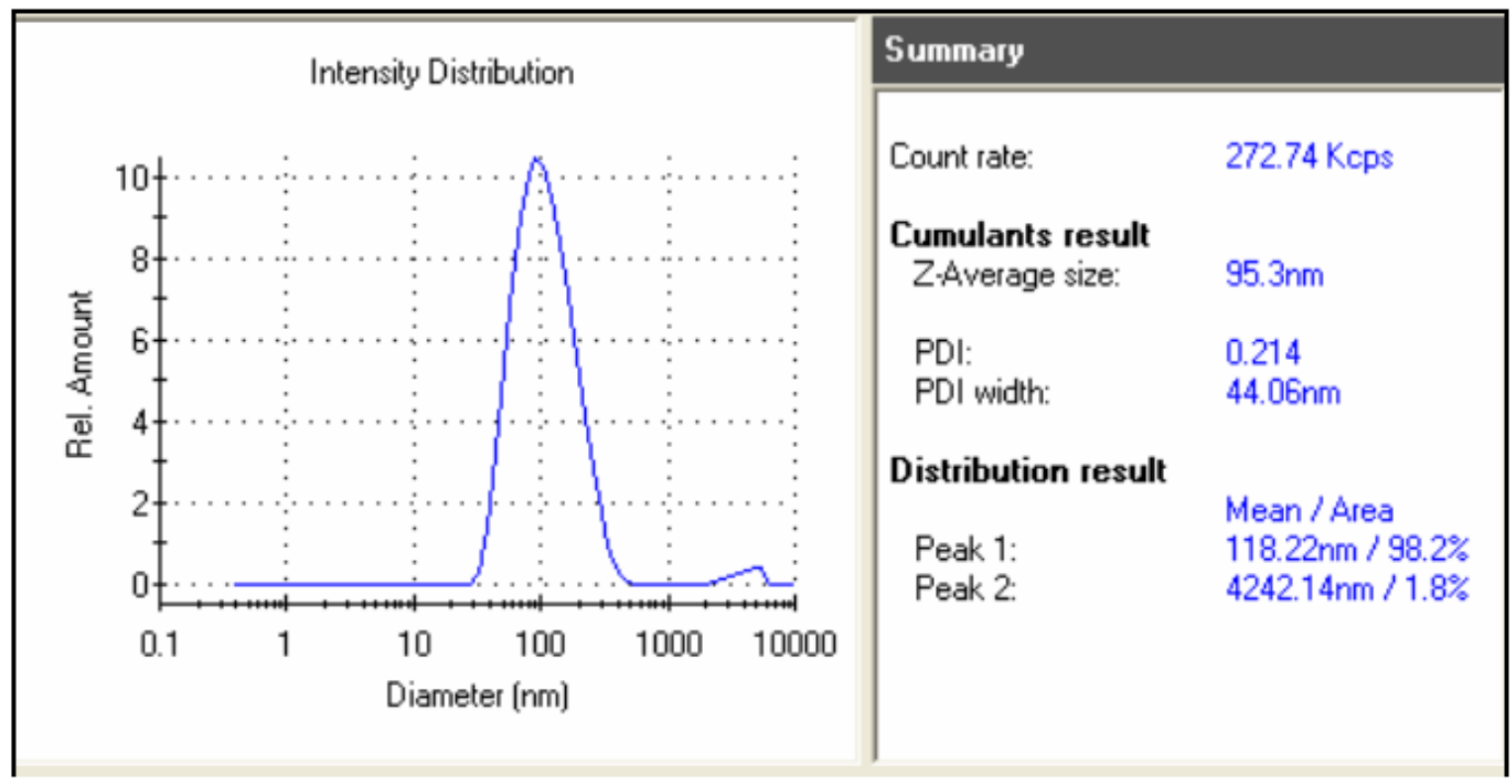

Figure 3. Particle size and size distribution of poly(HEMA-MAGA) nanoparticles.

ribution of poly(HEMA-MAGA) nanoparticles. The average size and size distribution of nanoarticles in suspension form were obtained by zeta sizer as about $95.3 \mathrm{~nm}$ with a polydispersity index (PDI) of 0.214 .

AFM was also used to evaluate the morphology and size distribution of the prepared nanoparticles. Figure 2. shows AFM image of poly(HEMA-MAGA) nanoparticles. The average size and spherical morphology of $\mathrm{Fe}^{3+}$ imprinted poly(HEMA-MAGA) nanoparticles was determined and confirmed by AFM. AFM images shows that the poly(HEMA-MAGA) nanoparticles are spherical and uniform with maximum size recorded as $93.7 \mathrm{~nm}$. The average sizes of $\mathrm{Fe}^{3+}$ imprinted poly(HEMA-MAGA) nanoparticles were recorded by zeta size analyzer as $95.3 \mathrm{~nm}$, which was in conformity with AFM observations.

The chemical structure and functional groups content of the poly(HEMA-MAGA) nanoparticles were confirmed by FTIR analysis. It can be clearly seen that characteristic stretching vibration bands for the poly(HEMA-MAGA) nanoparticles were observed in FTIR spectrum in Figure 4.

The broad peak observed near $3442 \mathrm{~cm}^{-1}$ was assigned to $-\mathrm{OH}$ stretching vibrations while the characteristic strong stretching vibration band at $1729 \mathrm{~cm}^{-1}$ was attributed to carbonyl groups. As it is seen in FTIR spectrum, due to the proportion of functional MAGA monomer in poly(HEMAMAGA) nanoparticles, carbonyl band was appeared quite intensive. Characteristic stretching vibration band amide I and amide II absorption bands were observed at $1637 \mathrm{~cm}^{-1}$ and $1454 \mathrm{~cm}^{-1}$, respectively as in Figure 4.

\section{$\mathrm{Fe}^{3+}$ Removal Experiments from Aqueous Solutions Effect $\mathrm{pH}$ on $\mathrm{Fe}^{3+}$ removal efficiency}

Since $\mathrm{pH}$ plays a important role in metal-chelate formation, the effect of $\mathrm{pH}$ on the $\mathrm{Fe}^{3+}$ removal efficiency of poly(HEMA-MAGA) nanoparticles was investigated. Experiments were carried out at different $\mathrm{pH}$ values of iron solutions ranging from 2.0 to 7.0. The $\mathrm{pH}$ dependence of $\mathrm{Fe}^{3+}$ adsorption onto $\mathrm{Fe}^{3+}$ imprinted poly(HEMA-MAGA) nanoparticles was shown in Figure 5 . As clearly seen here, maximum $\mathrm{Fe}^{3+}$ adsorption was achived at $\mathrm{pH}$ 4.0. $\mathrm{Fe}^{3+}$ imprinted poly(HEMA-MAGA) nanoparticles exhibited high affinity to $\mathrm{Fe}^{3+}$ ions in acidic medium than basic one. This means that the carboxyl groups of the MAGA monomer on the surface of the nanoparticles deprotonated to carboxylate form in acidic $\mathrm{pH}$. Hereby, electorostatic interaction between nanoparticles and $\mathrm{Fe}^{3+}$ ions was enhanced. $\mathrm{Fe}^{3+}$ adsorption at $\mathrm{pH} 4.0$ with an initial concentration of $5 \mathrm{mg} . \mathrm{L}^{-1}$ was reached to maximum value of $23.6 \mathrm{mg}$. $\mathrm{g}^{-1}$. This can be explained by the fact that, at this $\mathrm{pH}$, most of pendant carboxyl groups are protonated. This results indicate that $\mathrm{Fe}^{3+}$ imprinted poly(HEMA-MAGA) nanoparticles is suitable for $\mathrm{Fe}^{3+}$ removal at gastric $\mathrm{pH}$.

Significantly lower removal capacities were obtained with in more acidic and in more alkaline $\mathrm{pH}$ regions. The decrease in the $\mathrm{Fe}^{3+}$ removal capacity in more aci- 


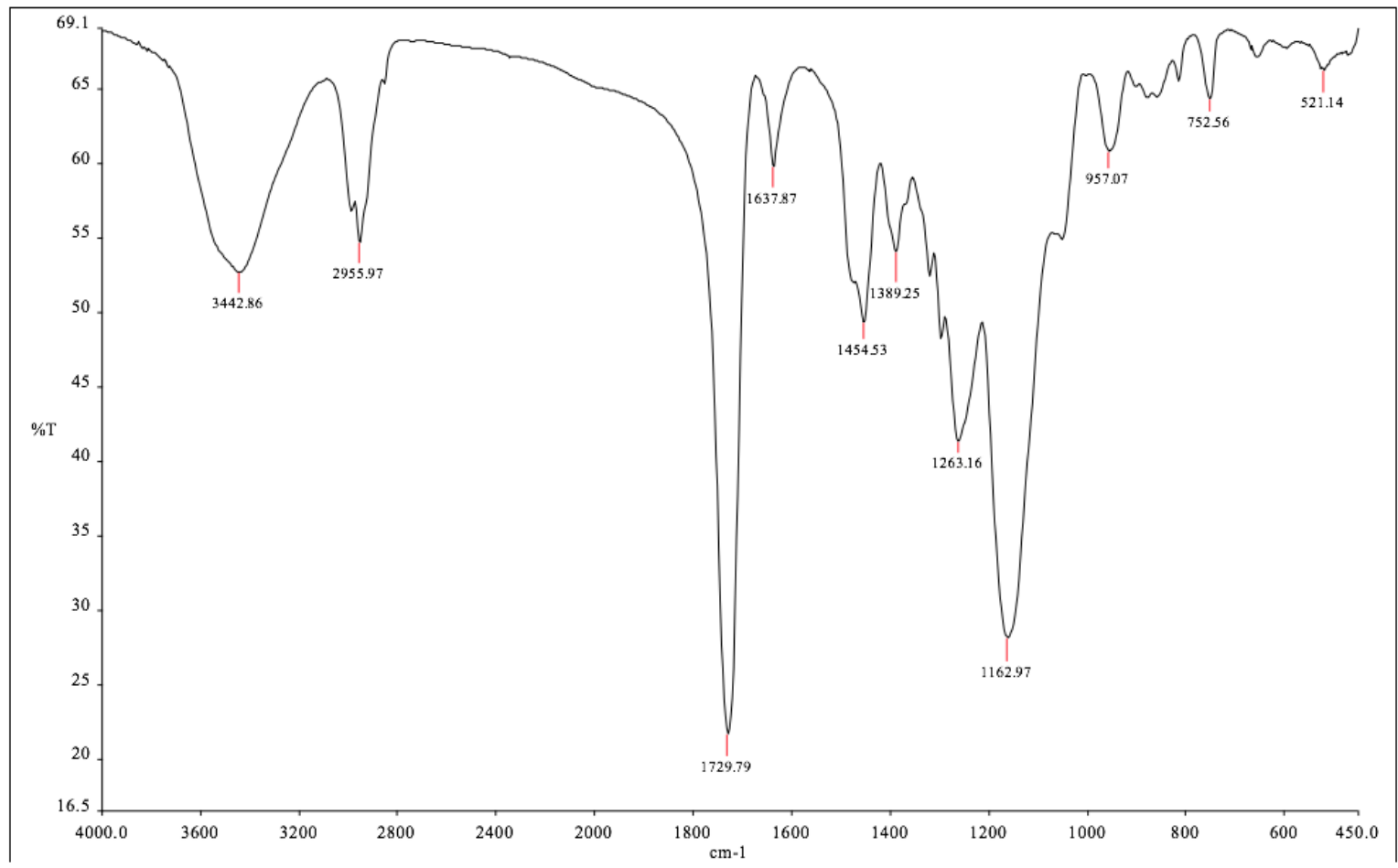

Figure 4. FTIR spectrum of poly(HEMA-MAGA) nanoparticles.

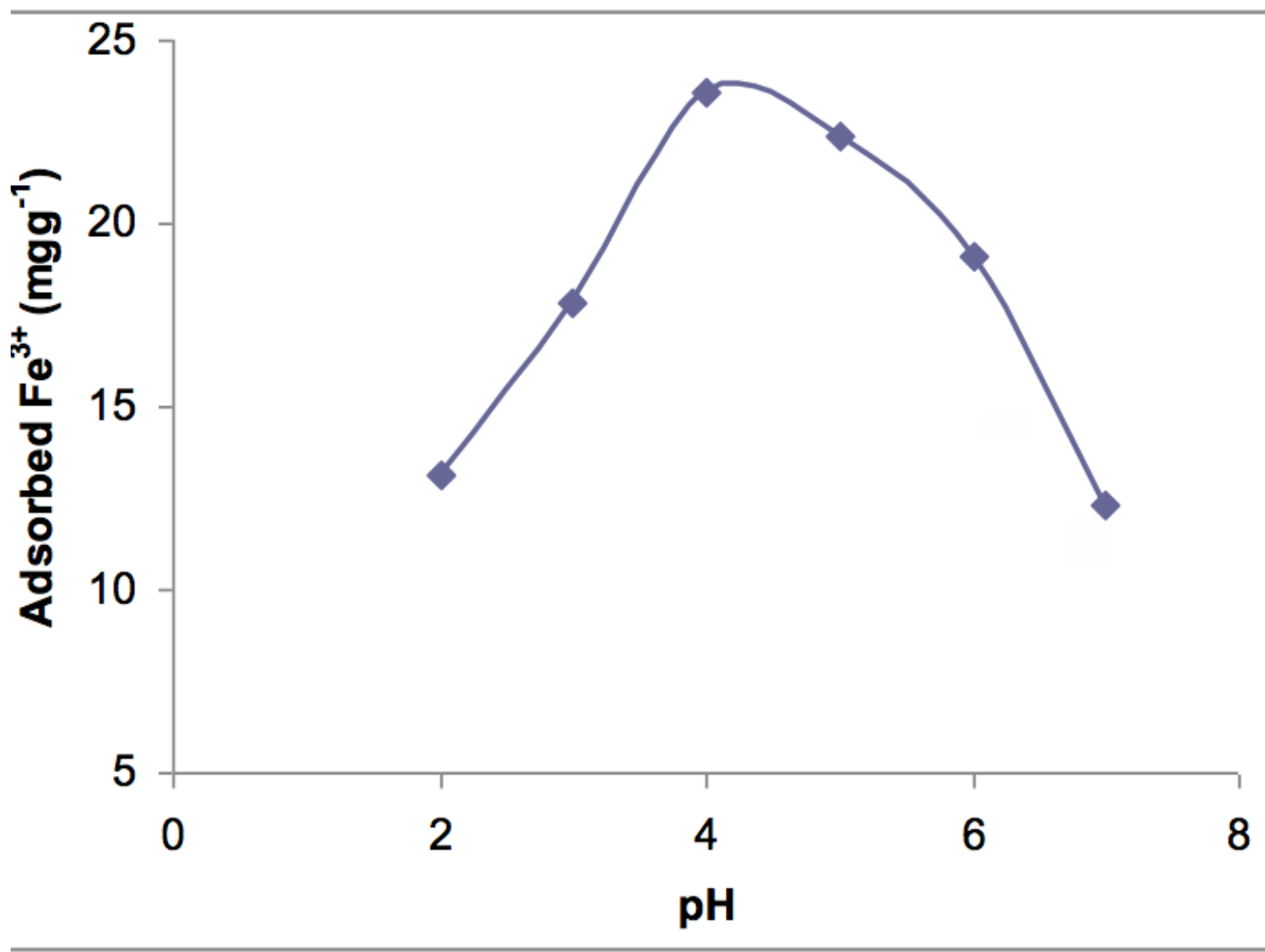

Figure 5. Effect of $\mathrm{pH}$ on $\mathrm{Fe}^{3+}$ removal capacity of poly(HEMA-MAGA) nanoparticles. İnitial concentration of Fe ${ }^{3+}: 5 \mathrm{mg} \cdot \mathrm{L}^{-1} ; \mathrm{T}: 25^{\circ} \mathrm{C}$. 
dic and more alkaline $\mathrm{pH}$ regions can be attributed to electrostatic repulsion effects between $\mathrm{Fe}^{3+}$ ions and charged carboxyl.

\section{Effect of Contact Time on $\mathrm{Fe}^{3+}$ removal efficiency}

All acute poisoning time is very important for treatment, because the poison should be removed before acces of $\mathrm{Fe}^{3+}$ ions to blood circulation system. After swallow of the toxic substans like iron, oral chelator should form insoluble and nontoxic complex in intestinal system through the faecal excretion routes. Figure 6 shows time dependent adsorption of the $\mathrm{Fe}^{3+}$ ions on to the poly(HEMA-MAGA) polymeric nanochelators. As seen in figure, iron adsorption reached equilibrium in $60 \mathrm{mi}$ nutes, and mostly $\mathrm{Fe}^{3+}$ ions removed in 20 minutes. Due to the large surface area of the poly(HEMA-MAGA) nanoparticles, $\mathrm{Fe}^{3+}$ ions were removed very rapidly when comparing with conventional adsorbents.

Effect of $\mathrm{Fe}^{3+}$ ions concentration in solution on $\mathrm{Fe}^{3+}$ removal efficiency was investigated and the results were shown in Figure 7. The amount of $\mathrm{Fe}^{3+}$ ions bound onto the poly(HEMA-MAGA) nanoparticles increased with increasing $\mathrm{Fe}^{3+}$ concentration and then reached a satu- ration value (i.e., $204,8 \mathrm{mg} . \mathrm{g}^{-1}$ ) at ion concentraiton of $50 \mathrm{mg} . \mathrm{L}^{-1}$, which represents saturation of the active binding ionic cavities on $\mathrm{Fe}^{3+}$ imprinted poly(HEMA-MAGA) nanoparticles. It becomes constant when $\mathrm{Fe}^{3+}$ concentration is greater than $50 \mathrm{mg} . \mathrm{L}^{-1}$. The maximum adsorption capacity was found to be $204.8 \mathrm{mg} \cdot \mathrm{g}^{-1} \mathrm{dry}$ weight of poly(HEMA-MAGA) nanoparticles. This value means that only 1 gr polymeric chelater can remove $60 \mathrm{mg} \mathrm{Fe}^{3+}$ contains 4 iron tablets from the medium.

\section{Results of selectivity experiments}

Selectivity is an important parameter for MIP chelating agent. In order to determine $\mathrm{Fe}^{3+}$ ion recognition capability of ion-imprinted poly(HEMA-MAGA) nanoparticles, selectivity experiments carried out in the presence of competitive ions such as $\mathrm{Cd}^{2+}, \mathrm{CO}^{2+}, \mathrm{Cr}^{3+}, \mathrm{Ni}^{2+}, \mathrm{Pb}^{2+}, \mathrm{Zn}^{2+}$, $\mathrm{Mn}^{2+}$ and $\mathrm{Ni}^{2+}$ in a batch system. These ions were chosen as competitive metal ions because of their similar ionic radii or ionic charges. Although these ions have similar chemical property, the competitive adsorption capacity of the $\mathrm{Fe}^{3+}$ imprinted poly(HEMA-MAGA) nanoparticles for $\mathrm{Fe}^{3+}$ ions is higher than competitive ions. Table 1. summarizes $K_{d^{\prime}}$ and $k$, values of competitive ions with respect to $\mathrm{Fe}^{3+}$ ions.

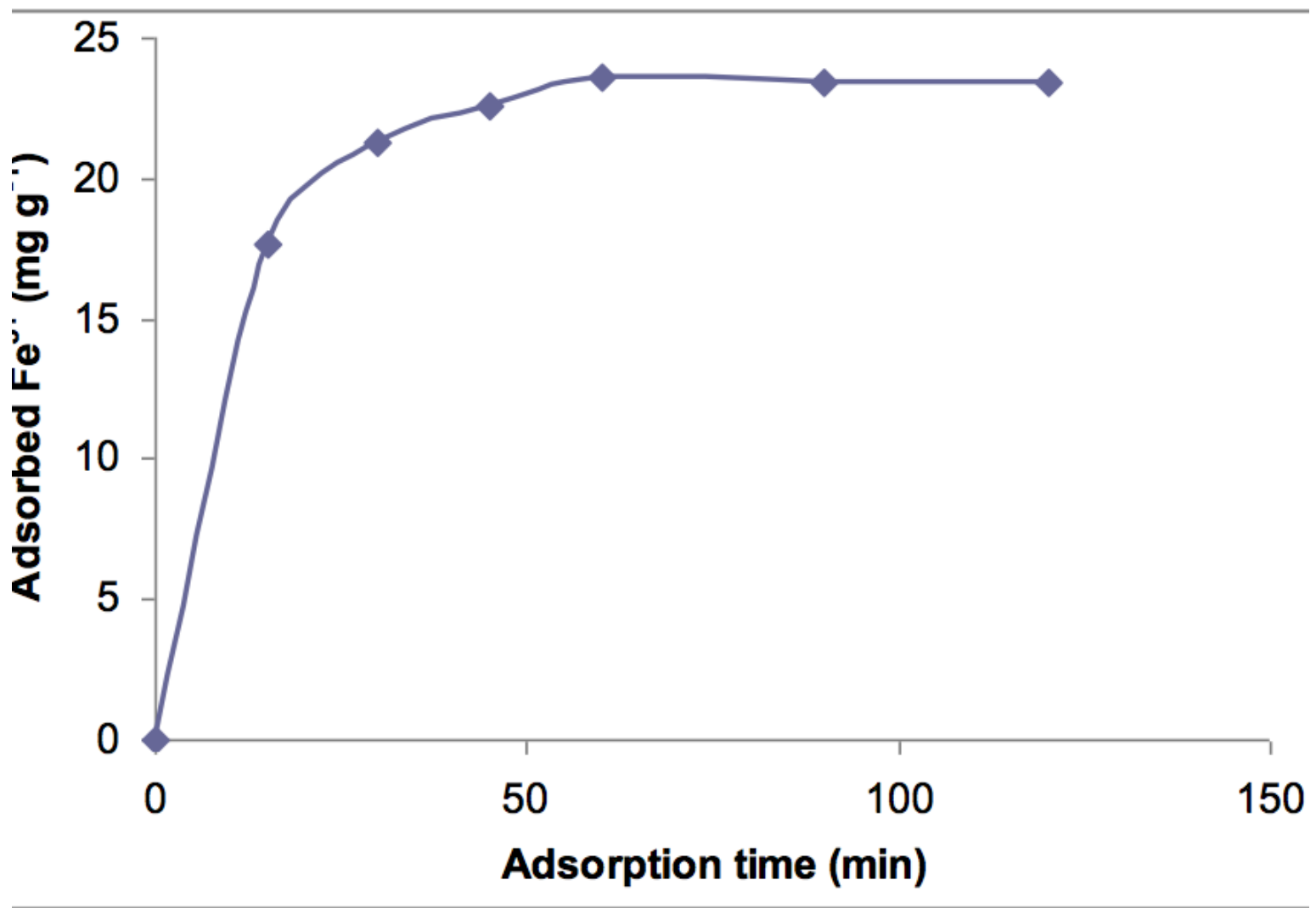

Figure 6. Effect of incubation time on $\mathrm{Fe}^{3+}$ removal capacity of the poly(HEMA-MAGA) nanoparticles: $\mathrm{pH}: 4.0$; Initial concentration of $\mathrm{Fe}^{3+}: 5 \mathrm{mg} . \mathrm{L}^{-1} ; \mathrm{T}: 25^{\circ} \mathrm{C}$. 


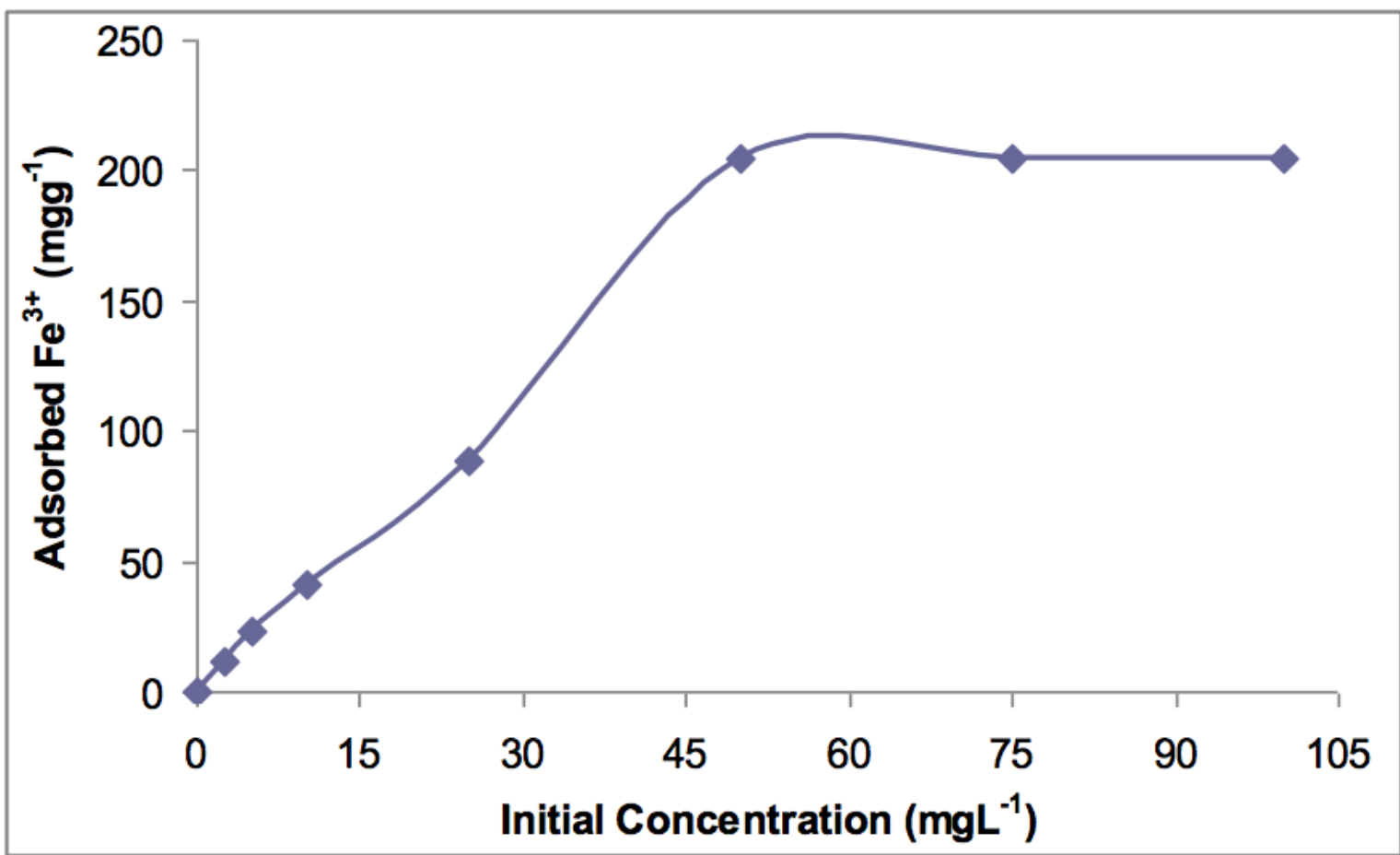

Figure 7. Effect of $\mathrm{pH}$ on $\mathrm{Fe}^{3+}$ removal capacity of poly(HEMA-MAGA) nanoparticles. İitial concentration of Fe ${ }^{3+}: 5 \mathrm{mg} . \mathrm{L}^{-1} ; \mathrm{T}: 25^{\circ} \mathrm{C}$.

The distribution coefficients $\left(K_{d}\right)$, selectivity coefficients $(k)$ and the relative selectivity coefficients $\left(k^{\prime}\right)$ of ions were calculated as expressed above. The results of selectivity coefficients for each ion were listed in Table 1. The distribution coefficient $\left(\mathrm{K}_{d}\right)$ of $\mathrm{Fe}^{3+}$ ions for $\mathrm{Fe}^{3+}$ imprinted poly(HEMA-MAGA) nanoparticles was significantly greater than the competitive ions.

The relative selectivity coefficient $\left(k^{\prime}\right)$ defines the imprinting effect for $\mathrm{Fe}^{3+}$ imprinted poly(HEMA-MAGA) nanoparticles with respect to non-imprinted poly(HEMA-
MAGA) nanoparticles. $\mathrm{Fe}^{3+}$ imprinted poly(HEMAMAGA) nanoparticles were possess $\mathrm{Fe}^{3+}$ ion recognition cavities on the surface, the selectivity coefficients values $\left(\mathrm{k}^{\prime}\right)$ of the $\mathrm{Fe}^{3+}$ imprinted poly(HEMA-MAGA) nanoparticles for $\mathrm{Fe}^{3+} / \mathrm{Cd}^{2+} \mathrm{Fe}^{3+} / \mathrm{CO}^{2+}, \mathrm{Fe}^{3+} / \mathrm{Cr}^{3+}, \mathrm{Fe}^{3+} / \mathrm{Ni}^{2+}, \mathrm{Fe}^{3+} /$ $\mathrm{Pb}^{2+}, \mathrm{Fe}^{3+} / \mathrm{Zn}^{2+}$ and $\mathrm{Fe}^{3+} / \mathrm{Mn}^{2+}$ almost were 196.5, 241.2, 218.3,191.5, 164.7, 147.2 and 252.8 fold higher than the non-imprinted poly(HEMA-MAGA) nanoparticles, respectively. The high selectivity of the $\mathrm{Fe}^{3+}$ imprinted poly(HEMA-MAGA) nanoparticles is due to the well designed coordination geometry of incorporated MAGA

Table 1. $k_{d}, k$, and $k^{\prime}$ values of competitive ions with respect to iron.

\begin{tabular}{cccccc}
\hline \multirow{2}{*}{ Metal Ion } & \multicolumn{2}{c}{ Imprinted NPs } & \multicolumn{2}{c}{$\mathrm{k}^{\prime}$} \\
\hline & $\mathrm{Kd}\left(\mathrm{mL} \mathrm{g}^{-1}\right)$ & $\mathrm{k}$ & $\mathrm{Kd}\left(\mathrm{mL} \mathrm{g}^{-1}\right)$ & $\mathrm{k}$ \\
\hline $\mathrm{Fe}^{3+}$ & 648.2 & - & 39388.5 & - & 196.5 \\
\hline $\mathrm{Cd}^{2+}$ & 573.1 & 1.1 & 182.2 & 216.2 & 241.2 \\
\hline $\mathrm{Co}^{2+}$ & 522.6 & 1.2 & 136.1 & 289.4 & 218.3 \\
\hline $\mathrm{Cr}^{3+}$ & 696.4 & 0.9 & 200.4 & 196.5 & 191.5 \\
\hline $\mathrm{Ni}^{2+}$ & 487.3 & 1.3 & 158.2 & 249.0 & 164.7 \\
\hline $\mathrm{Pb}^{2+}$ & 562.5 & 1.2 & 199.3 & 197.6 & 147.2 \\
\hline $\mathrm{Zn}^{2+}$ & 632.7 & 1.0 & 267.5 & 303.4 & 147.2 \\
\hline $\mathrm{Mn}^{2+}$ & 518.6 & 1.2 & 129.8 & & 252.8
\end{tabular}


molecules and $\mathrm{Fe}^{3+}$ ions. Selectivity results indicated that through ion-imprinting process, polymeric nanoparticles gained high selectivity for template $\mathrm{Fe}^{3+}$ ions due to the formed selective cavities.

\section{Adsorption of $\mathrm{Fe}^{3+}$ from intestinal mimicking solution} In order to understand the in vivo performance of $\mathrm{Fe}^{3+}$ removal capacity of $\mathrm{Fe}^{3+}$ imprinted poly(HEMA-MAGA) nanoparticles, biorelevant media was used. Biorelevant media content was closely mimic the intestinal fluid of small intestine. An ionic strength and $\mathrm{pH}$ corresponding to that found in intestine was adjusted by addition of sodium hydroxide and potassium dihydrogen phosphate. To mimic in vivo conditions, experiments were carried out at $37^{\circ} \mathrm{C}, \mathrm{pH} ; 4$, and stirred magnetically at 200 rpm for $2 \mathrm{~h}$.

Testing of $\mathrm{Fe}^{3+}$ removal performance in intestinal mimicking with $\mathrm{Fe}^{3+}$ imprinted poly(HEMA-MAGA) nanoparticles was provide us accurate prediction of behavier of chelating agent. After 30 minutes of the additon of the nanoparticles, the nanoparticle was removed from the medium and $\mathrm{Fe}^{3+}$ ion consantration of the medium was determined by IOCP. The amount of $\mathrm{Fe}^{3+}$ removed from the medium was calculated by subtracting the amount of $\mathrm{Fe}^{3+}$ ions before and after treatment with $\mathrm{Fe}^{3+}$ imprin- ted poly(HEMA-MAGA) nanoparticles. Time dependent $\mathrm{Fe}^{3+}$ removal performance of the polymer was showed in Figure 8.

The amount of the removed $\mathrm{Fe}^{3+}$ ions from intestinal mimicking medium by $\mathrm{Fe}^{3+}$ imprinted poly(HEMA-MAGA) nanoparticles was higher than aqueous medium. 90\% of $\mathrm{Fe}^{3+}$ ions removal from the intestinal mimicking medium was achived almost in 20 minutes by $\mathrm{Fe}^{3+}$ imprinted poly(HEMA-MAGA) nanoparticles. $\mathrm{Fe}^{3+}$ ions removal capacity of the $\mathrm{Fe}^{3+}$ imprinted poly(HEMA-MAGA) nanoparticles from medium was 206.4 mg. g $^{-1}$ polymer. These results were higher than $\mathrm{Fe}^{3+}$ removal capacity from aqueous solutions. Increasing of the removal capacity may be explained by the revealing the active functional groups of the polymer in the biorelevant solutions. So chemical chelations was increased with increasing the number of the revealed active sites.

\section{Conclusion}

Although acute iron poisoning is most common problem for children under age 6 years, there is no more orally active chelating agent. In this study, development of a polymeric $\mathrm{Fe}^{3+}$ chelating alternative agent was aimed. Due to the shortcoming of the clinically used chelating agents in effectiveness at GI tract and short plasma life we prepared

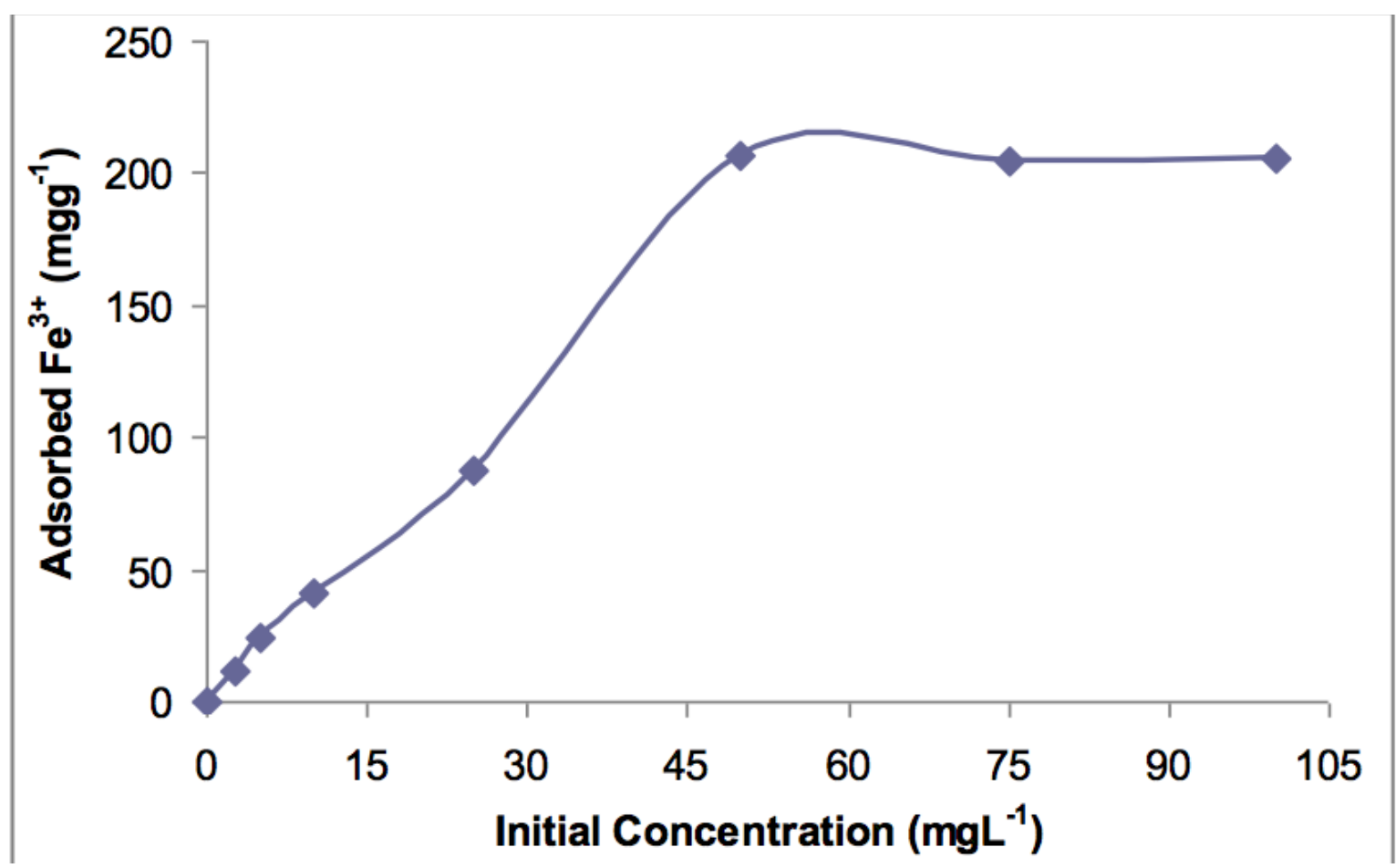

Figure 8. $\mathrm{Fe}^{3+}$ removal performance of the poly(HEMA-MAGA) nanoparticles in intestinal mimicking medium: $\mathrm{pH}: 4.0 ; \mathrm{T}: 37^{\circ} \mathrm{C}$. 
acrylate based nanosized polymer, which contains glutamic acid as iron chelating agent. The iron selectivity of the polymer was enhanced by molecular imprinting techniques. The size and shape of the polymer were provided rapid removal capability and high adsorption capacity.

Ergün et al. [21] prepared $\mathrm{Fe}^{3+}$ imprinted poly(GMA-MAC) (MIP) beads embedded PHEMA composite cryogel for selective removal of $\mathrm{Fe}^{3+}$ ions from $b$-thalassemia patient plasma. The maximum adsorption amount of $\mathrm{Fe}^{3+}$ ions was $2.23 \mathrm{mg} \cdot \mathrm{g}^{-1}$. composite cryogels. Polomoscanik et al. [23] prepared Hydroxamic Acid-Containing hydrogel for $\mathrm{Fe}^{3+}$ chelation. poly(2-hydroxyethyl)acrylate (HEA) based hydrogel have been synthesized as potential nonabsorbed chelators for iron in the gastrointestinal tract. The maximum adsorption capacity was $81 \mathrm{mmol} . \mathrm{g}^{-1}$ hydrogels. Zhou et al. [24] synthesized 3-hydroxypyridin-4-one hexadentate ligand-containing copolymers for to reduce the efficiency of iron absorption from the intestine by administering iron chelators. 3-Hydroxypyridin-4-one Hexadentate ligand synthesized and incorporated into polymers by copolymerisation with $\mathrm{N}$,Ndimethylacrylamide (DMAA), and $\mathrm{N}, \mathrm{N}^{\prime}$-ethylene-bis-acrylamide (EBAA). Their $\mathrm{Fe}^{3+}$ binding capacity was $271 \mu \mathrm{mol} . \mathrm{g}^{-1}$ polymers. Yavuz et al. [31] investigated $\mathrm{Fe}^{3+}$ removal performance of $\mathrm{Fe}^{3+}$ imprinted poly(HEMA-MAGA) beads and poly(HEMA-MAGA) membranes [32] from iron overdosed human plasma. Their adsorption capacity was $92.6 \mu \mathrm{mol} . \mathrm{g}^{-1}$ for beads and $164.2 \mu \mathrm{mol} . \mathrm{g}^{-1}$ for membranes. In this study $\mathrm{Fe}^{3+}$ imprinted poly(HEMA-MAGA) nanoparticles was synthesized for iron removal in the Gl tract and reached about 206,4 mg.g ${ }^{-1}$ $\mathrm{Fe}^{3+}$ adsorption capacity in IMS.

Several methods were generated for elimination of excessive iron ions from body but, most of them aimed to remove of iron from tissues originated blood transfusion based disease. Many research groups have focused to developt novel chelating agent for oral treatment. Among these approaches, polymeric chelating agents have become attractive for researchers by their low cost, ready to preparation, non toxic effects and usefull in harsh condition like stomac solutions. In the light of the above discussion, we believe that $\mathrm{Fe}^{3+}$ imprinted poly(HEMA-MAGA) nanoparticles offeres the promising strategy with high removal capacity with specificity and efficiency of $\mathrm{Fe}^{3+}$ ions.

\section{References}

1. G. Papanikolaoua, K. Pantopoulos, Iron metabolism and toxicity, Toxicol. Appl. Pharmacol., 202 (2005) 199-211.

2. J. Wang, K. Pantopoulos, Regulation of cellular iron metabolism, Biochem. J., 434 (2011) 365-381.

3. $H$. Lindsay, H. Allen, Iron supplements: scientific Issues concerning efficacy and Implications for research and programs, J. Nutr., 132 (2002) 813-819.

4. S. Jeffrey, S. Fine, Iron Poisoning, Curr. Probl. Pediatr. Adolescent Health Care, 303 (2000) 71-90.

5. R.S. Britton, K.L. Leicester, B.R. Bacon, Iron toxicity and chelation therapy, Int. J. Hematol. 76 (2002) 219-228.

6. G. Crisponi, M. Remelli, Iron chelating agents for the treatment of iron overload., Coord. Chem. Rev., 252 (2008) 1225-1240.

7. H. Heli, S. Mirtorabi, K. Karimian, Advances in iron chelation: an update, Expert. Opin. Ther. Patents., 21 (2011) 819-856.

8. D.R. Richardson And P. Ponka, Pyridoxal isonicotinoyl hydrazone and its analogs: Potential orally effective ironchelating agents for the treatment of iron overload disease, J. Lab. Clin. Med., 131 (1998) 306-316.

9. J.B. Mowry, D.A. Spyker, D.E. Brooks, A Zimmerman, J.L. Schauben, Annual report of the american association of poison control centers' national poison data system (NPDS): 33rd Ann. Rep. Clin Toxicol. (Phila), 54 (2016) 924-1109.

10. J.R. Mahoney, Jr., P.E. Hallaway, B.E. Hedlund, J.W. Eaton, Acute iron poisoning rescue with macromolecular chelators, J. Clin. Invest., 84 (1989)1362-1366.

11. M. Berkovitch, A. Livne, G. Lushkov, M. Segal, C. Talmor, Y. Bentur, J. Klein, G. Koren, The efficacy of oral deferiprone in acute iron poisoning, Am. J. Emerg Med., 18 (2000) 36-40.

12. M. Yassin, A.T. Soliman, V. De Sanctis, A young adult with unintended acute intravenous iron intoxication treated with oral chelation: The use of liver ferriscan for diagnosing and monitoring tissue iron load, Mediterr. J. Hematol. Infect. Dis., 9 (2017) 1-6.

13. H. Halil, N. Tuygun, E. Polat, C. Demir Karacan, Minimum ingested iron cut-off triggering serious iron toxicity in children, Pediatr. Inter. 61 (2019) 444-448.

14. H.F. Gomez, H.H. Mc Clafferty, D. Flory, J. Brent, R.C Dart, Prevention of gastrointestinal ıron absorption by chelation from an orally administered premixed deferoxamine/ charcoal slurry, Ann. Emerg. Med., 30 (1997) 587-592.

15. D. Zu, R.C. Hider, Design of Clinically Useful Iron(III)-Selective Chelators, Med. Res. Rev., 22 (2002) 26- 64

16. D.Y. Liu, Z. D. Liu, R.C Hider, Oral iron chelators-development and application, Best Pract. Res. Clin. Haematol., 15 (2002) 369- 384.

17. M.R. Gumber, V.B. Kute, P.R. Shah, A.V. Vanikar, H.V. Patel, M.R. Balwani, P.P. Ghuge, H.L. Trivedi, Successful treatment of severe Iron ıntoxication with gastrointestinal decontamination, deferoxamine, and hemodialysis, Renal Failure, 35 (2013) 729-731.

18. D. Zu, R.C. Hider, Design of iron chelators with therapeutic application, Coord. Chem. Rev., 232 (2002) 151-171.

19. R. Paul, E.P. Hallaway, G.J. Hanson, A.E. Berger, B. Bernard, B.E. Hedlund, First human studies with a high-molecularweight iron chelator, J. Lab. Clin. Med., 135 (2000) 57-65.

20. P. Mirhoseini, M.A.R Astaraei, A. Karimi, M. Moshirib, L. Etemad, M. Zeinali, G. Karimi, Efficacy of orally administered montmorillonite for acute iron poisoning detoxification in rat, J. Appl. Clay, 103 (2015) 62-66. 
21. B. Ergün, G. Baydemir, M. Andaç, H. Yavuz, A. Denizli, Ion imprinted beads embedded cryogels for in vitro removal of iron from b-thalassemic human plasma, J. Appl. Polym. Sci., 125 (2012) 254-262.

22. Z.D. LIU, H.H. Khodr, S.L. Lu, R.C. HIder, Design, synthesis and evaluation of $\mathrm{N}$-Basic substituted 3-Hydroxypyridin-4-ones: orally active iron chelators with lysosomotrophic potential, J. Pharm. Pharmacol., 52 (2000) 263-272.

23. S.C. Polomoscanik, C.P. Cannon, T.X. Neenan, S.R.H. Farley, W. Mandeville, P.K. Dhal, hydroxamic acid-containing hydrogels for nonabsorbed Iron chelation therapy: synthesis, characterization, and biological evaluation, Biomacromolecules, 6 (2005) 2946-2953.

24. T. Zhou, X.L. Kong, Z.D. Liu, D. Yong Liu, R.C. Hider, Synthesis and iron(III)-chelating properties of novel 3-hydroxypyridin4-one hexadentate ligand-containing copolymers, Biomacromolecules, 9 (2008) 1372-1380.

25. M.I. ul-haq, J.L. Hamilton, B.F.L. Lai, R.A. Shenoi, S. Horte, I. Constantinescu, H.A. Leitch, J.N. Kizhakkedathu, Design of long circulating nontoxic dendritic polymers for the removal of Iron in vivo, ACS Nano, 7 (2013) 10704-10716.

26. J.L. Hamilton, J.N. Kizhakkedathu, Polymeric nanocarriers for the treatment of systemic iron overload, Mol. Cell. Therap., 3 (2015) 1-15

27. T. Zhoua, G. Winkelmannb, Z.Y. Daia, R.C. Hider, Design of clinically useful macromolecular iron chelators, J. Pharm. Pharmacol., 63 (2011) 893-903.

28. N.A.A. Rossi, I. Mustafa, J.K. Jackson, H.M. Burt, S.A. Horte, M.D. Scott, J.N. Kizhakkedathu, In vitro chelating, cytotoxicity, and blood compatibility of degradable poly(ethylene glycol)-based macromolecular iron chelators, Biomaterials, 30 (2009) 638-648.

29. T. Zhou, H. Neubert, D.Y. Liu, Z.D. Liu, Y.M. Ma, X.L. Kong, W. Luo, S. Mark, R.C. Hider, Iron binding dendrimers: a novel approach for the treatment of haemochromatosis, J. Med. Chem., 49 (2006) 4171- 4182.

30. S. Özkara, M. Andaç, V. Karakoç, R. Say, A. Denizli, Ionimprinted PHEMA based monolith for the removal of Fe3+ ions from aqueous solutions, J. Appl. Polym. Sci., (120) (2011) 1829-1836.
31. H. Yavuz, R. Say, A. Denizli, Iron removal from human plasma based on molecular recognition using imprinted beads, Mater. Sci. Engin. C, 25 (2005) 521-528.

32. H. Yavuz, M. Andaç, L. Uzun, R. Say, A. Denizli, Molecular recognition based iron removal from human plasma with imprinted membranes, Int. J. Art. Org., 29 (2006) 900 -911.

33. K. Sarkaya, M. Bakhshpour, A. Denizli, $\mathrm{Ag}^{+}$ions imprinted cryogels for selective removal of silver ions from aqueous solutions, Sep. ScI. Tech., 54 (2019) 2993-3004.

34. E.A. Turkoglu, M. Bakhshpour, A. Denizli, Molecularly imprinted biomimetic surface plasmon resonance sensor for hormone detection, Bıoınterf. Res. Appl. Chem., 9 (2019) 4090-4095.

35. A. Derazshamshir, I. Gokturk, E. Tamahkâr, F. Yilmaz, N. Saglam, A. Denizli, Phenol removal from wastewater by surface imprinted bacterial cellulose nanofibres, Env. Techn., 40 (2019) 1-13.

36. C. Esen, R.H. Senay, E. Feyzioglu, S. Akgol, Poly(hydroxyethyl methacrylate-co-methacryloylglutamic acid) nanospheres for adsorption of $\mathrm{Cd} 2+$ ions from aqueous solutions, J Nanopart. Res., 16 (2014) 2255-2261.

37. V. Karakoc, E. Yılmaz, D. Türkmen, N. Öztürk, S. Akgöl, A. Denizli, Selective separation of human serum albumin with copper(II) chelated poly(hydroxyethyl methacrylate) based nanoparticles, Int. J. Bı. Macromol., 45 (2009) 188-193.

38. Y. Saylan, F. Yilmaz, A. Derazshamshir, E. Yilmaz, A. Denizli, Synthesis of hydrophobic nanoparticles for real-time lysozyme detection using surface plasmon resonance sensor, J. Mol. Recog., 30 (2017) 1-7.

39. E.B. Altintas, H. Yavuz, R. Say, A. Denizli, Methacryloyl amido glutamic acid having porous magnetic beads as a stationary phase in metal chelate affinity chromatography, J. Bıomater. ScI. Polym. Edt., 17 (2006) 213-226.

40. B. Sellergren, J. Wieschemeyer, K.S. Boos, D. Seidel, Imprinted polymers for selective adsorption of cholesterol from gastrointestinal fluids, Chem. Mater., 10 (1998) 40374046 . 